\title{
PENGARUH PREFERENSI MEREK, PERSEPSI KUALITAS, PERSEPSI HARGA TERHADAP MINAT BELI ULANG PADA CV BASIMBAH TANI-LABUHANBATU
}

\author{
Eka Setiawati ${ }^{1}$, Rizki Syahputra ${ }^{2}$ \\ ${ }^{1}$ Alumni Sarjana Ekonomi STIE Labuhanbatu \\ ${ }^{2}$ Dosen STIE Labuhanbatu
}

\begin{abstract}
Abstrak
Pemasaran merupakan salah satu kegiatan pokok yang dilakukan oleh perusahaan untuk mempertahankan kelangsungan aktivitas perusahaan, tetapi dalam pemasaran modern seperti sekarang ini paradigma pemasaran telah berubah, tidak hanya menciptakan transaksi untuk mencapai keberhasilan pemasaran, tetapi perusahaan juga harus memperhatikan kepuasan pelanggan dalam waktu yang panjang. Penelitian ini bertujuan untuk menganalisis pengaruh preferensi merek, persepsi kualitas, persepsi harga secara serempak terhadap minat beli ulang. Objek penelitian adalah CV. Basimbah Tani Labuhanbatu dengan sampel 100 orang. Penarikan sampel menggunakan rumus slovin sehingga menjadi 97 sampel. Teknik pengambilan sampel menggunakan metode aksidental sampling. Teknik pengumpulan data dilakukan dengan kuesioner atau data sekunder. Teknik analisis data menggunakan analisis regresi linier berganda dengan software SPSS. Hasil penelitian menunjukkan secara serempak variabel independent yaitu variabel preferensi merek, persepsi kualitas dan persepsi harga mempunyai pengaruh yang signifikan terhadap minat beli ulang. Secara individual variabel preferensi merek, persepsi kualitas dan persepsi harga pada penelitian ini mempunyai pengaruh yang signifikan terhadap minat beli ulang.
\end{abstract}

Kata Kunci : $\quad$ Preferensi Merek, Persepsi Kualitas, Persepsi Harga, Minat Beli Ulang.

\section{PENDAHULUAN}

Keputusan pelanggan melakukan minat beli juga menjadi salah satu hal penting terwujudnya kepuasan pelanggan, menurut Roslina (2009) mengemukakan bahwa minat beli seringkali digunakan sebagai sarana dalam menganalisis perilaku pelanggan. Terjadinya minat beli yang tinggi mencerminkan adanya tingkat kepuasan pelanggan ketika memutuskan untuk menggunakan suatu produk. Minat beli ulang pelanggan akan terjadi berdasarkan keputusan pembelian yang pernah dilakukan sebelumnya. Saat konsumn merasa puas maka akan timbul minat pembelian ulang sesuai kembali. Minat pembelian ulang adalah suatu proses dimana pelanggan mulai melakukan pengambilan keputusan sesudah melakukan pembelian dari suatu produk yang telah ditawarkan atau yang dibutuhkan oleh pelanggan tersebut.

\section{TINJAUAN PUSTAKA Minat Beli Ulang}

Niat pembelian ulang didefinisi sebagai pertimbangan individu terkait dengan pembelian ulang suatu produk dari suatu. Kotler (2008), mengartikan bahwa minat adalah sesuatu yang pribadi dan berhubungan dengan sikap, individu yang berminat terhadap suatu obyek akan mempunyai kekuatan atau dorongan untuk melakukan seorangkaian tingkah 
laku untuk mendekati atau mendapatkan objek tersebut. Minat beli ulang merupakan perilaku yang muncul sebagai respon terhadap objek yang menunjukkan keinginan pelanggan untuk melakukan pembelian ulang.

\section{Preferensi Merek}

Preferensi merek merupakan salah satu bentuk apresiasi pelanggan terhadap merek. Menurut Halim, Dharmayanti, Brahmana (2014) brand preference merupakan kecenderungan seorang pelanggan untuk menyukai sebuah merek dibandingkan yang lainnya sehingga akan membentuk keinginannya untuk membeli merek tersebut. Menurut Ardhanari (2008) mengatakan bahwa preferensi merek yang kuat mempunyai derajat kesukaan pelanggan yang kuat terhadap suatu merek. Perusahaan yang mampu mengembangkan preferensi merek akan mampu mempertahankan serangan dari para pesaing. Preferensi merek terbaik dapat memberikan jaminan kualitas bagi pelanggannya.

\section{Persepsi Kualitas}

Persepsi kualitas (perceived quality) menurut Aaker (1997) dalam Puspitasari (2006) dapat didefinisikan sebagai persepsi pelanggan terhadap keseluruhan kualitas atau keunggulan suatu produk atau jasa layanan berkaitan dengan apa yang diharapkan oleh pelanggan. Satu hal yang harus selalu diingat, yaitu bahwa persepsi kualitas merupakan persepsi para pelanggan, oleh sebab itu persepsi kualitas tidak dapat ditetapkan secara objektif. Selain itu, persepsi pelanggan akan melibatkan apa yang penting bagi pelanggan karena setiap pelanggan memiliki kepentingan yang berbeda-beda terhadap suatu produk atau jasa. Maka dapat dikatakan bahwa membahas persepsi kualitas berarti akan membahas keterlibatan dan kepentingan pelanggan.

\section{Persepsi Harga}

Menurut Hawkins dan Mothersbaugh (2013) menjelaskan harga adalah jumlah uang yang harus membayar untuk mendapatkan hak untuk menggunakan produk. Zeithmal dalam Kurniawan , Santoso dan Dwiyanto (2007) menyatakan bahwa persepsi harga merupakan sesuatu yang dikorbankan oleh pelanggan untuk mendapatkan suatu produk. Menurut Kurniawan, Santoso dan Dwiyanto (2007) Faktor terpenting dari harga sebenarnya bukan harga itu sendiri (objective price), akan tetapi harga subyektif, yaitu harga yang dipersepsikan oleh pelanggan. Artinya, pelanggan mungkin memandang produk adalah produk berkualitas oleh karena itu wajar bila memerlukan pengorbanan uang yang lebih mahal.

Stanton dalam Iryanita dan Sugiarto (2013) menjelaskan ada tiga ukuran yang menentukan harga, yaitu harga yang sesuai dengan kualitas produk, harga yang sesuai dengan manfaat produk, dan perbandingan harga dengan produk lain. Persepsi adalah proses dimana seseorang mengorganisir dan menginterpretasikan kesan dari panca indera dalam tujuan untuk memberikan arti bagi lingkungan mereka. Harga (price) menurut Kotler dan Amstrong, (2006) adalah jumlah uang yang harus dikeluarkan (dibayarkan) oleh konsumen, untuk memperoleh produk barang atau jasa. Sedangkan menurut Cannon (2009), harga adalah sesuatu yang harus diberikan oleh konsumen untuk mendapatkan keunggulan yang ditawarkan oleh bauran pemasaran perusahaan Cannon (2009). Menurut Swastha (2007), mendefinisikan harga adalah sejumlah uang yang 
dibutuhkan untuk mendapatkan sejumlah barang dan pelayanan.

\section{Kerangka Konseptual}

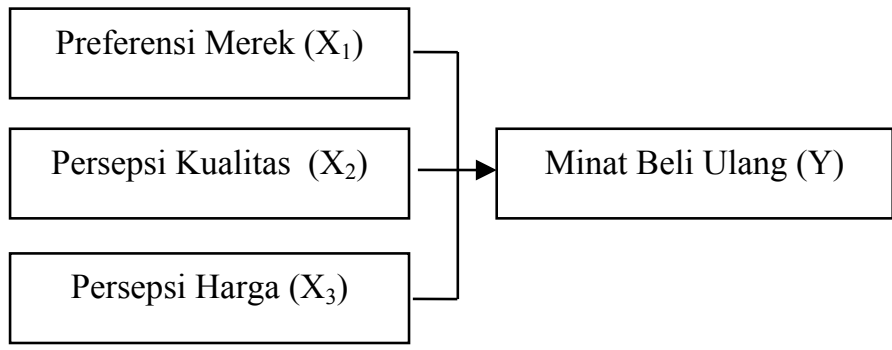

\section{Gambar 1 Kerangka Konseptual}

Hipotesis penelitian yang diajukan pada penelitian ini adalah :

1. Preferensi merek secara parsial berpengaruh terhadap minat beli ulang.

2. Persepsi kualitas secara parsial berpengaruh terhadap minat beli ulang.

3. Persepsi harga secara parsial berpengaruh terhadap minat beli ulang.

4. Preferensi merek, persepsi kualitas dan persepsi kualitas berpengaruh secara serempak terhadap minat beli ulang.

\section{METODE PENELITIAN}

Pada penelitian ini sampel yang digunakan adalah 96,04 responden atau dapat dibulatkan menjadi 100 orang responden. Teknik pengambilan sampel menggunakan metode aksidental sampling.

Variabel yang digunakan pada penelitian ini adalah :

1. Variabel independen

- Preferensi merek

- Persepsi kualitas

- Persepsi harga

2. Variabel dependen
- Minat beli ulang

Sumber data yang digunakan dalam penelitian ini adalah data primer dan data sekunder. Metode pengumpulan data dengan menyebarkan kuesioner dan studi pustaka.

\section{HASIL PENELITIAN}

Hasil Analisis Regresi Linier Berganda

Pada bagian ini akan dilakukan analisis data mengenai pengaruh preferensi merek, persepsi kualitas dan persepsi harga berpengaruh terhadap mempunyai pengaruh yang signifikan terhadap minat beli ulang. Hasil penelitian ini telah diolah komputer melalui program SPSS (Statistical Product and Service Solutions) dengan analisis regresi linier berganda. Berdasarkan data dari hasil penelitian tersebut maka secara lengkap hasil analisa regresi linier berganda yang telah dilakukan dapat dilihat pada Tabel 4.1di bawah:

Tabel 1

Hasil Regresi Linier Berganda

\begin{tabular}{|c|c|c|c|c|}
\hline Variabel & $\begin{array}{c}\text { Koefisien } \\
\text { Regresi }\end{array}$ & $\begin{array}{c}\text { Standar } \\
\text { Error }\end{array}$ & $\mathbf{t}_{\text {hitung }}$ & Sig. \\
\hline $\begin{array}{l}\text { Preferensi } \\
\text { merek } \\
\text { Persepsi } \\
\text { kualitas } \\
\text { Persepsi harga }\end{array}$ & $\begin{array}{l}0,246 \\
0,402 \\
0,212\end{array}$ & $\begin{array}{l}0,089 \\
0,082 \\
0,084\end{array}$ & $\begin{array}{l}2,752 \\
4,889 \\
2,524\end{array}$ & $\begin{array}{l}0,007 \\
0,000 \\
0,013\end{array}$ \\
\hline $\begin{array}{l}\text { Constanta } \\
\text { Koefisien Deter } \\
\text { Koefisien Korel } \\
\text { F }_{\text {hitung }} \\
\text { Sig. } \\
\square=5 \%\end{array}$ & $\begin{array}{l}\operatorname{lasi}\left(\mathrm{R}^{2}\right) \\
(\mathrm{R})\end{array}$ & $\begin{array}{l}49 \\
88 \\
21 \\
97 \\
0\end{array}$ & & \\
\hline
\end{tabular}

Sumber : Hasil Penelitian, Data Diolah (2016)

Tabel 4.1 menunjukan bahwa model yang digunakan untuk menduga pengaruh tersebut adalah :

$$
Y=1,649+0,246 X_{1}+0,402 X_{2}+0,212 X_{3}
$$




\section{Pengujian Hipotesis}

a) Hasil Uji Serempak (Uji F)

Untuk mengetahui apakah variabel independent secara simultan (bersama-sama) mempunyai pengaruh terhadap variabel dependent atau tidak berpengaruh maka digunakan uji $\mathrm{F}$ (Ftest) yaitu dengan cara membandingkan $\mathrm{F}$ hitung dengan $\mathrm{F}_{\text {tabel. }}$ Kriteria pengujiannya adalah jika $\mathrm{F}_{\text {hitung }}>\mathrm{F}_{\text {tabel }}$ maka $\mathrm{H}_{\mathrm{o}}$ ditolak dan $\mathrm{H}_{\mathrm{a}}$ diterima, sedangkan apabila $\mathrm{F}_{\text {hitung }}$ $<\mathrm{F}_{\text {tabel }}$ maka $\mathrm{H}_{\mathrm{o}}$ diterima dan $\mathrm{H}_{\mathrm{a}}$ ditolak. Dari hasil analisis regresi berganda dengan menggunakan $\mathrm{Df}_{1}=4$ dan $\mathrm{Df}_{2}=$ 100 diperoleh $\mathrm{F}$ tabel sebesar 2,470. Sedangkan $\mathrm{F}$ hitungnya diperoleh sebesar 52,397 sehingga dari perhitungan di atas dapat diketahui bahwa $\mathrm{H}_{\mathrm{o}}$ ditolak dan $\mathrm{H}_{\mathrm{a}}$ diterima.

Berdasarkan hasil tersebut maka menunjukkan bahwa variabel independent yaitu variabel preferensi merek, persepsi kualitas dan persepsi harga mempunyai pengaruh yang signifikan terhadap minat beli ulang. Hasil uji tersebut dapat membuktikan bahwa hipotesis I yang diajukan dalam penelitian terbukti diterima, yang menyatakan bahwa variabel preferensi merek, persepsi kualitas dan persepsi harga mempunyai pengaruh yang signifikan terhadap minat beli ulang.

b) Hasil Uji Parsial (Uji t)

Untuk mengetahui pengaruh masing-masing variabel independent, yaitu variabel preferensi merek, persepsi kualitas dan persepsi harga mempunyai pengaruh yang signifikan terhadap minat beli ulang maka digunakan uji $\mathrm{t}(\mathrm{t}-$ test $)$ dengan cara membandingkan nilai $t_{\text {hitung }}$ dengan $t_{\text {tabel }}$. Dengan derajat kebebasan (degree of freedom) sebesar 95\% ( $\square=$ $5 \%$ ) diperoleh $\mathrm{t}_{\text {tabel }}$ sebesar 1,660.
Tabel 2

Hasil Uji Parsial

Coefficients $^{\mathrm{a}}$

\begin{tabular}{|l|c|c|}
\hline \multicolumn{1}{|c|}{ Variabel } & $\mathbf{t}$ hitung & $\mathbf{t}$ tabel \\
\hline Preferensi Merek & 2,752 & 1,660 \\
& & \\
Persepsi Kualitas & 4,889 & 1,660 \\
Persepsi Harga & 2,524 & 1,660 \\
\hline
\end{tabular}

Sumber : Hasil Penelitian, Data Diolah (2016)

Dari uraian hasil $t_{\text {hitung }}$ dan $t_{\text {tabel }} d i$ atas menunjukkan bahwa variabel preferensi merek, persepsi kualitas dan persepsi harga pada penelitian ini mempunyai pengaruh yang signifikan terhadap minat beli ulang. Hal ini disebabkan karena $\mathrm{t}_{\text {hitung }}>\mathrm{t}_{\text {tabel }}$ sehingga seluruh variabel menerima $\mathrm{H}_{\mathrm{a}}$.

\section{Pembahasan}

Hasil analisis secara keseluruhan dapat membuktikan bahwa :

1. Dalam penelitian ini preferensi merek memiliki tanda positif signifikan terhadap minat beli ulang. Pada wawancara yang dilakukan keseluruhan responden, mengenal baik pupuk CV Basimbah Tani dan pernah menggunakannya. Preferensi merek sangat dibutuhkan untuk meningkatkan minat pembeli memilih produk tersebut. Dimana hasil penelitian mengungkapkan responden lebih memilih pupuk $\mathrm{CV}$ Basimbah Tani dibandingkan merek lain. Semakin tinggi pelanggan yang menggunakan pupuk $\mathrm{CV}$ Basimbah Tani dan menyukai pupuk CV Basimbah Tani dibanding yang lain, maka terdapat kesempatan yang besar untuk pelanggan memiliki minat beli ulang dan mengutamakan produk 
CV Basimbah Tani sebagai pupuk yang digunakan.

2. Dalam penelitian ini persepsi kualitas signifikan berpengaruh terhadap minat beli ulang pada $\mathrm{CV}$ Basimbah Tani Labuhanbatu. Persepsi kualitas merupakan penilaian pelanggan terhadap keunggulan atau superioritas produk secara keseluruhan. Oleh sebab itu, perceived quality didasarkan pada evaluasi subyektif pelanggan (bukan manajer atau pakar) terhadap kualitas produk. Persepsi pelanggan akan melibatkan apa yang penting bagi pelanggan karena setiap pelanggan memiliki kepentingan yang berbeda terhadap produk atau jasa. Sedemikian pentingnya peran persepsi kualitas bagi suatu merek sehingga upaya membangun persepsi kualitas yang kuat harus dapat merebut dan menaklukkan pasar di setiap kategori produk. Membangun persepsi kualitas harus diikuti peningkatan kualitas nyata dari produknya karena akan sia-sia meyakinkan pelanggan bahwa kualitas merek produknya adalah tinggi bilamana kenyataan menunjukkan kebalikannya. Hal ini karena pelanggan yang pada tahap awal memutuskan untuk membeli produk karena persepsi kualitasnya, pada gilirannya akan sampai pada tahap evaluasi yang menghantarkan pada rasa puas atau tidak.

3. Dalam penelitian ini persepsi harga membuktikan memiliki pengaruh pada minat beli ulang CV Basimbah Tani Labuhanbatu. Penilaian yang dirasakan setiap pelanggan terhadap suatu produk maupun jasa yang mereka terima tidak sama. Persepsi pelanggan terhadap suatu harga dapat mempengaruhi keputusannya dalam membeli suatu produk sehingga suatu perusahaan harus mampu memberikan persepsi yang baik terhadap produk atau jasa yang mereka jual. Penetapan harga mempunyai tujuan sebagai berikut:

a) Memperoleh laba yang maksimum

b) Mendapatkan pangsa pasar tertentu

c) Mencapai tingkat hasil penerimaan penjualan maksimum pada waktu itu

d) Mencapai keuntungan yang ditargetkan

e) Mempromosikan produk

\section{KESIMPULAN DAN SARAN}

\section{Kesimpulan}

Berdasarkan dari penelitian mengenai Pengaruh Preferensi Merek, Persepsi Kualitas, Persepsi Harga Terhadap Minat Beli Ulang Pada CV Basimbah Tani-Labuhanbatu sebagai berikut :

1. Secara serempak variabel independent yaitu variabel preferensi merek, persepsi kualitas dan persepsi harga mempunyai pengaruh yang signifikan terhadap minat beli ulang.

2. Secara individual variabel preferensi merek pada penelitian ini mempunyai pengaruh yang signifikan terhadap minat beli ulang.

3. Secara individual variabel persepsi kualitas pada penelitian ini mempunyai pengaruh yang signifikan terhadap minat beli ulang.

4. Secara individual variabel persepsi harga pada penelitian ini mempunyai pengaruh yang 
signifikan terhadap minat beli ulang.

\section{Saran}

Berdasarkan penelitian yang telah dilakukan di CV Basimbah TaniLabuhanbatu. Maka penulis memberikan saran yang dapat dijadikan masukan dari penulis kepada pihak CV Basimbah TaniLabuhanbatu yaitu :

1. CV Basimbah Tani-Labuhanbatu dalam menjaga daya tarik atau minat untuk membeli pelanggan dan berkunjung ke CV Basimbah Tani-Labuhanbatu dalam status harga gengsi, penetapan harga murah, pemberian diskon khusus perlu diperhatikan secara baik untuk untuk lebih memuaskan kepada pelanggan karena apabila penetapan harga murah, status harga gengsi dan pemberian diskon baik maka minat atau keinginan pelanggan untuk membeli pecel lele akan meningkat.

2. Pihak manajemen pemasaran $\mathrm{CV}$ Basimbah Tani-Labuhanbatu perlu berbenah diri untuk meningkatkan kinerjanya dengan meningkatkan pengetahuan dan keahlian kerja agar menjadi professional dibidangnya dengan cara melakukan analisa lingkungan dan lokasi yang tepat untuk membuka sebuah bisnis

3. Minat Beli Pelanggan CV Basimbah Tani-Labuhanbatu sebagian pelanggan kurang memiliki dorongan untuk berkunjung ke CV Basimbah Tani-Labuhanbatu. Maka dari itu pihak manajemen pemasaran harus terus berbenah diri untuk menarik pelanggan agar berkunjung pada CV Basimbah Tani-Labuhanbatu seperti hal lainnya melakukan promosi yang gencar dan pemerhatian kepuasan pelanggan yang pernah berkunjung perlu ditingkatkan agar loyalitas pelanggan dapat tercipta.

4. CV Basimbah Tani-Labuhanbatu diharapkan lebih memperhatikan apa yang diinginkan pelanggan khususnya pada penetapan harga dan lokasi dan meningkatkan kinerja pegawai guna menciptakan minat beli pelanggan.

\section{DAFTAR PUSTAKA}

Akhdon. 2011. Cara Menggunakan dan Memaknai Path Analysis (Analisis Jalur). Bandung : Alfabeta.

Ardhanari, Margaretha, 2008. Customer Satisfaction Pengaruhnya TerhadapBrand Preference dan Repurchase Intention Private Brand, Jurnal Riset Ekonomi dan Bisnis

Http://amandabrownies.co.id/pr oducts (5, Volume 8 Nomor 2 hal 58-68.

Cannon, Joseph P., William D. Perreault, And E. Jerome. Mccarthy. 2008. Pemasaran Dasar-Pendekatan Manajemen Global. Jakarta: Salemba Empat.

Ciptadi, Ikhsan. 2010. Pengaruh Dari Persepsian Kualitas, Persepsian Nilai, Kepuasan Konsumen, dan Preferensi Merek Pada Niat Pembelian Ulang (Studi Pada Produk Rumah Makan King Fried Chicken). Skripsi Fakultas Ekonomi Universitas Sebelas Maret Surakarta. 
Dwityanti, Esthi. 2008. Analisis FaktorFaktor Yang Mempengaruhi Minat Beli Konsumen Terhadap Layanan Internet Banking Mandiri Studi Kasus Pada Karyawan Departemen Pekerjaan Umum Jakarta. Thesis Program Studi Magister Manajemen Program Pasca Sarjana Universitas Diponegoro. Semarang.

Ferdinan, Comaeni Enril. 2013. Analisis Pengaruh Persepsi Harga, Persepsi Kualitas Produk, Dan Promosi Terhadap Keputusan Pembelian Sepeda Motor Suzuki (Studi Pada Pembeli - Pengguna Sepeda Motor Suzuki di Kota Solo). Skripsi Fakultas Ekonomi Universitas Diponegoro. Semarang.

Griffin, Jill. 2009. Customer Loyalty: How to Learn It, How to Keep It. Jakarta. Erlangga.

Halim, Dharmayanti dan Brahmana, 2014, Pengaruh Brand Identity Terhadap Timbulnya Brand Preference dan Repurchase Intention Pada merek Toyota, Jurnal Manajemen Pemasaran Petra Vol. 2, No. 1, (2014) 111:2-3.

Hawkins, Del I. dan David L. Mothersbaugh. Consumer Behavior: Building Marketing Strategy. Elevent Edition.2010. New York: McGraw-Hill.

Iryanita, Rizky dan Y. Sugiarto. 2013. Analisis Pengaruh Citra Merek, Persepsi Harga dan Persepsi Kualitas Produk Terhadap Keputusan Pembelian (Studi pada Konsumen Produk ATBM Pekalongan). Journal of
Manajemen. Vol. 2. No. 2. pp. 19.

Kotler, Philip \& Armstrong, Gary. 2006. Prinsip-prinsip Pemasaran. Edisi Keduabelas. Erlangga. Jakarta.

Kotler, Philip. 2008. Manajemen Pemasaran, Edisi Milenium diterjemahkan Benyamin Molan, PT. Prenhallindo, Jakarta.

Lidyawati. 2008. Hubungan antara Intensitas Menonton Iklan di Televisi dengan Perilaku Konsumtif. Skripsi (tidak diterbitkan). Surakarta : Fakultas Psikologi UMS.

Puspitasari, Diana,2006. Analisis Pengaruh Persepsi Kualitas Dan Kepuasan Pelanggan Terhadap Minat Beli Ulang (Studi Kasus pada Maskapai Penerbangan Garuda Keberangkatan Semarang). Tesis, Fakultas Ekonomi Universitas Diponegoro, Semarang

Schiffman dan Kanuk. 2007. Perilaku Konsumen.Edisi Kedua. Jakarta: PT. Indeks Gramedia.

Shimp, Terence, A. 2007, Integrated Marketing Communication In Advertising and Promotion, Edisi Ketujuh, New York, McGrawHill

Sugiyono. 2010. Metode Penelitian Bisnis, Alfabeta, Bandung.

Sutisna. 2002. Perilaku Konsumen dan Komunikasi Pemasaran. Bandung: Penerbit PT. Remaja Rosdakarya.

Swastha. Basu. 2007. Manajemen Pemasaran. Edisi Kedelapan. Cetakan Kedelapan. Jakarta: Penerbit Liberty. 
Roslina 2009. Pengaruh Pengetahuan

Produk Dan Citra Merek

Terhadap Pembelian Produk. Jurnal Bisnis dan Manajemen Vol. X (2) 200-215

Tjiptono, Fandy. 2007. Strategi Pemasaran. Edisi ke dua, penerbit Andi, Yogyakarta

Yee, Choy Johnn., San, Ng Cheng., dan Khoon, dan Ch'ng Huck. 2011. Consumers' Perceived Quality, Perceived Value and Perceived Risk Towards Purchase Decision on Automobile. American Journal of Economics and Business Administration 3 (1): 47-57, 2011. ISSN 19455488 . 